\title{
A SATIRE ON THE INFLUENZA OF 1803
}

\author{
by
}

\section{RENATE BURGESS*}

ONE of the coloured engraved satires in the Wellcome collection is An Address of thanks from the Faculty to the Right Hon.ble Mr. Influenzy for his kind visit to this country (Fig. 1). It was designed by Temple West, an amateur artist whose name appears on the cross-bar of the commode on which the figure of Influenzy is seated. The print was published by S. W. Fores, 50 Piccadilly on 20 April 1803. There is also the inscription by the publishers "Folios of caracatures lent out for the evening."

Members of the public living in 1803 who were interested in medical matters would have taken this print home for amusement and they were probably familiar with the faces of the doctors in the picture. Their names do not appear on the print, as in all satires representing prominent people; but lines of their sayings appear above, connected by dotted lines with the mouth of each individual; these texts characterize the doctors' opinions and their professional attitudes.

The modern beholder of such satires, however, is at a loss to identify the persons and usually resorts for information to the British Museum's great Catalogue of political and personal satires. ${ }^{1}$ But this is of no avail in the case of our satire, as the Address of thanks only came into the possession of the British Museum after completion of the catalogue's volume VIII which deals with satires between the years 1801 and 1811.

However, in 1955 Dr. Peter John Taylor, then house physician to St. Thomas's Hospital, wrote an article about the print in St. Thomas's Hospital Gazette. ${ }^{2} \mathrm{He}$ states that after acquiring the print, he asked the British Museum and the Wellcome Historical Medical Library whether any work on the identification of the group had been done, and received negative replies. His own research at the Royal College of Physicians resulted in an interpretation of the historical background of the scene and in identification of two persons in the picture.

In his article he pointed out that the influenza epidemic raged through Western Europe and concentrated chiefly in France and England. He writes of a "temporary, if uneasy peace between this country and France" in 1803, which, however, turned into hostility during the second quarter of that year. Looking at the figure of Influenzy we perceive some political connotation. His headgear consists of a red pointed cap

*Renate Burgess, Ph.D., Keeper of Art Collections, Wellcome Institute for the History of Medicine, 183 Euston Road, London NW1 2BP.

1 Mary Dorothy George, Catalogue of political and personal satires in the Department of Prints and Drawings in the British Museum, vols. 7-11 [i.e. 1793-1832], London, British Museum, $1942-54$.

2 Peter John Taylor, 'A medical caricature, 1803', St. Thomas's Hosp. Gaz., ophthalmic issue, April 1955, pp. 68-70. 


\section{Short Articles}

or "bonnet rouge" which is tied by a white piece of fabric to his head; together with the blue eye-shield he wears, this colour combination reminds us of the stripes in the French flag. The red bonnet itself might be the well-known cap symbolizing France's revolutionary past. It appears in other, more overtly political satires of the period, for instance in James Gillray's French generals retiring on account of their health, with Lépeaux presiding in the directorial dispensary, 1799. ${ }^{3}$ Here the bonnet rouge is significantly perched on the gothic chair of Lépeaux. Influenzy's pronounced facial features appear un-English and are vaguely reminiscent of traditional satirical portraits of Napoleon. One could refer to the small figure of "Boney" in the print Doctor Sangrado curing John Bull of repletion-with the kind offices of clysterpipe \& little Boney, also done by James Gillray, 1803.4 These associations are too tempting not to suspect a political hint by the artist who sarcastically introduces Influenzy here as a Frenchman with a Napoleonic face "kindly visiting this country".

The nine physicians are doing homage to Influenzy for good reasons. Apart from an increase in their medical practice and remuneration, an occasion was given to distinguish themselves by submitting articles on the influenza epidemic to the Medical and Physical Journal. ${ }^{5}$ Here one reads: "The Catarrhal fever, or influenza, which has been for some weeks very generally diffused over this metropolis and its environs . . . is a subject of considerable interest to medical practitioners, and still more so to those who examine with a philosophic eye into the obscure causes of general epidemics ... and as it has seldom been of a nature to spread alarm and terror, it has excited all the attention due to so interesting an epidemic from the enquiring physician."

Some of the physicians who participated in this and an earlier influenza research, such as Dr. Richard Pearson, Dr. Falconer, and Sir George Baker can be identified in the print. So it seems likely that the information the artist received came from the side of those who had initiated the research or were participating in it. Other physicians appear for other reasons, possibly to demonstrate their connexion with the Royal College of Physicians of London.

Dr. Taylor identified the robust kneeling man in front of the group as Sir Walter Farquar (1738-1819). A capital "F" below his left hand gave the clue for a search through Munk's Roll. ${ }^{6}$ There he is listed at the time of the print as physician to the Prince of Wales. Having studied medicine in Edinburgh and Glasgow without graduation, he worked for some time as army physician and continued his studies in France. He settled in England as apothecary. In 1796 he suddenly obtained an M.D. (Aberdeen), a fellowship of the Royal College of Physicians, a baronetcy, and appointment as Physician-in-Ordinary to the Prince of Wales. Dr. Taylor explains this steep rise to fame by the fact that he acted as physician to the Prime Minister, William Pitt. The little red hand appearing above his staff is understood as the "Red Hand of

\footnotetext{
3 George, op. cit., note 1 above, vol. 7, 1942, no. 9403.

- Ibid., vol. 8, 1947, no. 9986.

- Critical analysis of the recent publications on the different branches of physic, surgery, and medical philosophy', Med. phys. J., 1803, 9: 377.

- William Munk, The roll of the Royal College of Physicians of London, London, Royal College of Physicians, 1878, vol. 2, p. 461.
} 


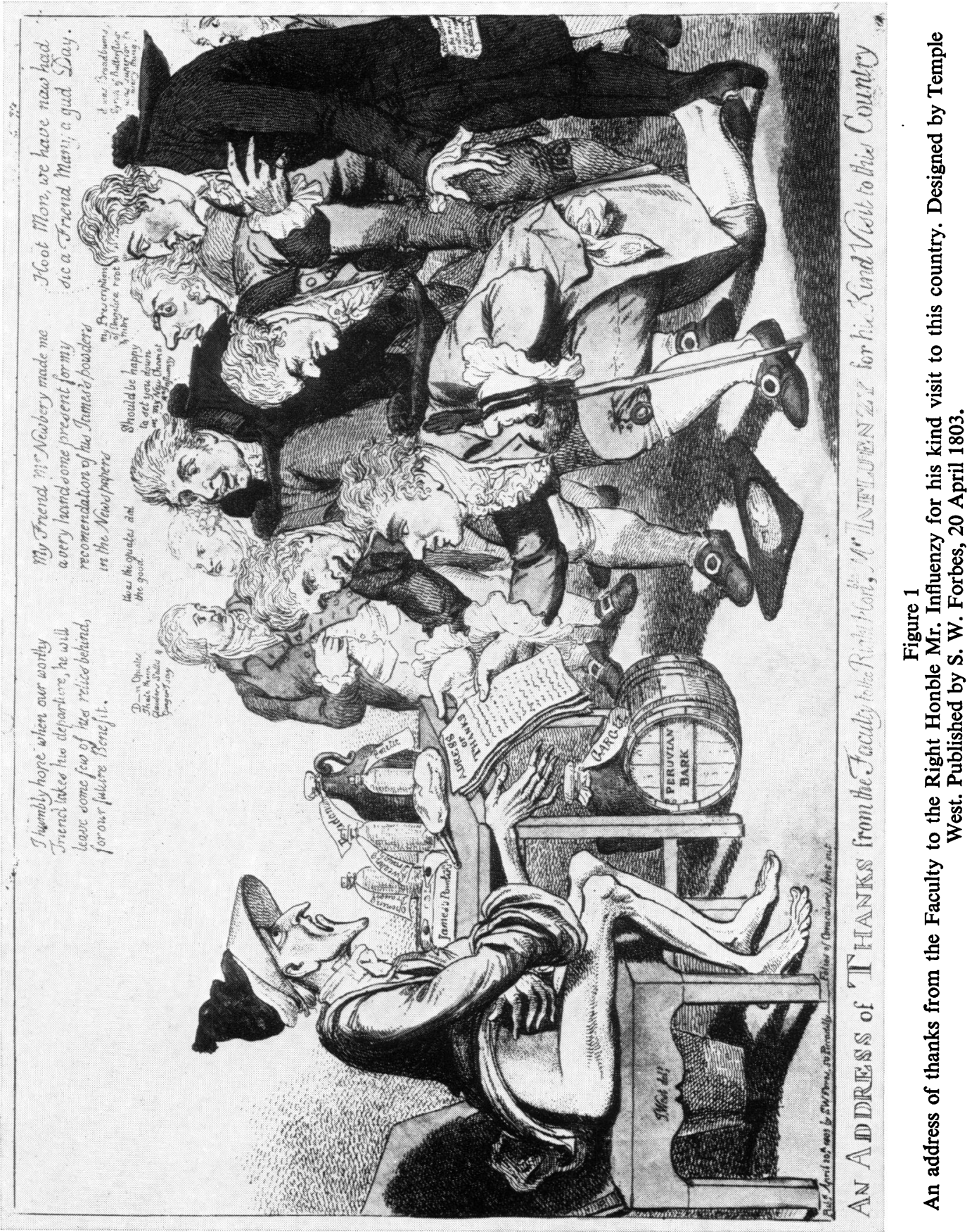




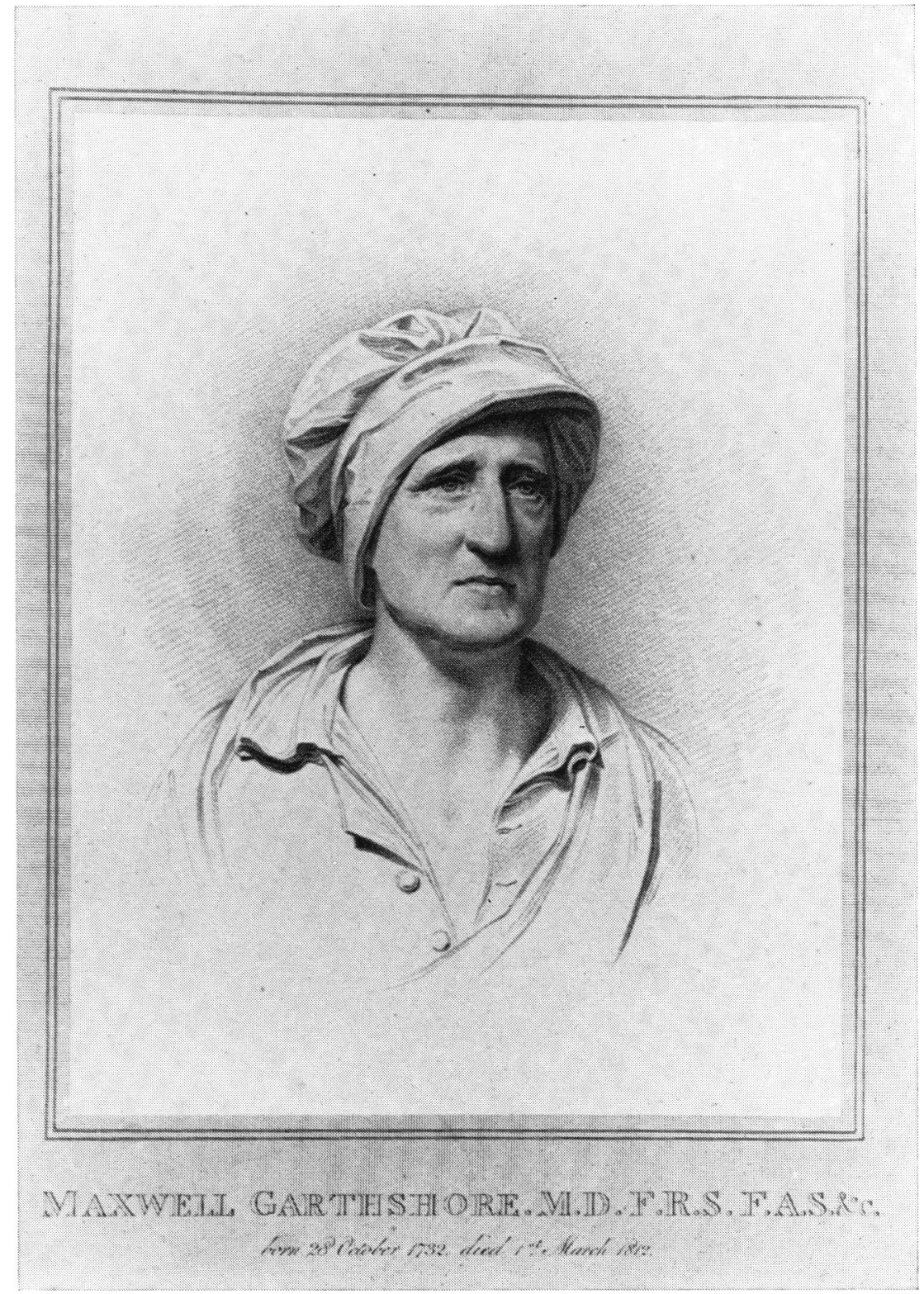

Figure 2.

Maxwell Garthshore. Lithograph by J. Collyer after J. Slater. 


\section{Short Articles}

Ulster", symbol for a baronetcy. A portrait of Sir Walter Farquar ${ }^{7}$ provides confirmation for this identification.

Another doctor discovered by Dr. Taylor is the man to the right of the back row who is wearing spectacles. It is Dr. James Ware, M.D., F.R.S. (1756-1815), ophthalmic surgeon to St. Thomas's Hospital. He was identified by comparison with his portrait in the "Founders" Picture ${ }^{8}$ of the Medical Society of London.

The most prominent author in the influenza research was Dr. Richard Pearson, ${ }^{8}$ M.D., L.R.C.P. (1765-1836), co-founder of the School of Medicine at Birmingham. He can be recognized as the urbane man who, together with Sir Walter Farquar, is holding the Address of Thanks. Comparison with his portrait by J. Posselwhite after a painting by Miss Bracken ${ }^{10}$ confirms this identity. His saying is: "I humbly hope when our worthy friend takes his departure, he will leave some few of his relics behind, for our future benefit."

To the right, behind him, appears an older doctor who is bowing deeply uttering the words: "Should be happy to set you down in my new chariot, Mr. Influenzy". His features are very close to those of Sir George Baker, M.D. (1722-1809), President of the Royal College of Physicians in 1785-90, 1792-93, and 1795. ${ }^{11} \mathrm{He}$ had written an article on the influenza of $1762 .{ }^{12}$

The tall, aristocratic-looking man to the right of him, standing in profile, with a mortar-board on his back presents some problems to the student of physiognomies. His saying is: "Hoot Man, we have now had [sic] a Friend many a gud day". There is definitely something Scottish about him. The first suggestion was that this could be Sir William Knighton, Bart. (1776-1836), physician and confidant to George IV. The only Scottish touch here is an early doctor title from St. Andrew's University in 1803. The words on a paper stuck in the figure's pocket are: "Accoucheur to the most exalted rank at Weymouth [and] elsewhere". This would fit Sir William Knighton's obstetrical career, which, however, took place from 1806 onwards, too late for our print of 1803 . Another, less well-known person might fit the portrait. Maxwell Garthshore (1732-1812) ${ }^{13}$ was born in Kirkcudbright, Scotland. He was apprenticed as surgeon at Edinburgh and took his M.D. degree at Edinburgh University in 1764, after a medical practice at Uppingham, Scotland. A good friend and advisor regarding his professional career was Sir George Baker (nearby in the print). Garthshore settled after 1764 in London where he practised chiefly as accoucheur.

${ }^{7}$ Renate Burgess, Catalogue of portraits of doctors and scientists in the Wellcome Institute for the History of Medicine, London, Wellcome Institute for the History of Medicine, 1973, no. 952.1.

${ }^{8}$ Members of the Medical Society of London (the 'Founders' picture). Painting by S. Medley, 1800, at the Medical Society of London. Key in J. J. Abraham, Lettsom. His life, times, friends and descendants, London, Heinemann, 1933, pp. 336-338.

- Richard Pearson, Some observations on the present epidemic catarrhal fever or influenza chiefly in relation to its modes of treatment to which are subjoined historical abstracts concerning the catarrhal fever of 1762, 1775 and 1782, London, C. \& R. Baldwin, 1803.

${ }_{10}$ Burgess, op. cit., note 7 above, no. 2259.1.

11 The Royal College of Physicians of London. Portraits, edited by Gordon Wolstenholme and described by David Piper, London, J. Churchill, 1964, pp. 46, 47.

12 Sir George Baker, De catarrho et de dysenteria Londinensi epidemicis utrisque an. 1762, libellus, London, 1764. Translated by E. Symes Thompson, Influenza or epidemic catarrhal fever, London, Percival, 1890, pp. 56-64.

${ }^{13}$ Munk, op. cit., note 6 above, vol. 2, p. 259. 


\section{Short Articles}

He obtained the fellowship of the Royal College of Physicians and of the Royal Society and was known for his high ethics, his "gaiety and briskness". ${ }^{14}$ All these facts would fit the saying of the figure and his expression but must be complemented by a portrait from the print collection of the Royal College of Physicians. ${ }^{15}$ It is by J. Collyer after J. Slater and represents Dr. Garthshore full-face, his head covered by a negligé cap (Fig. 2). Comparison of a frontal portrait with a profile, as that in the print, is beset with dangers; but it is obvious that the general formation of the features here and there are similar. In both portraits the nose is hooked, the underlip slightly protruding, the chin well formed, the overall shape of the face long and thin, with an intense expression that is transformed to gaiety in the satire. There still remains the written text on the paper in the pocket, "Accoucheur to the most exalted rank at Weymouth ....". That Garthshore was accoucheur in 1803 is certain, but the mentioning of Weymouth would bring a secondary meaning into the witty programme. Dr. Garthshore's son, William (1764-1806) ${ }^{16}$ was M.P. for Weymouth from 1796 until 1806, the date of his death.

The big, agitated man in the centre of the large figures must be George Pearson, M.D., F.R.C.P., F.R.S. (1751-1828), who was physician and lecturer on materia medica at St. George's Hospital, London. An anonymous engraved portrait ${ }^{17}$ shows the same formation of the face at rest which in the print has widely-opened eyes and lips. His saying is: "My friend Mr. Newbery made me a very handsome present for my recommendation of His James's powders in the Newspapers". This refers to an analysis of James's powders by Dr. G. Pearson written up in the Philosophical Transactions of $1791 ;^{18}$ in it he mentions that he bought a phial of James's powder from Mr. F. Newbery, and in the presence of three fellows broke the seal of the phial, took out the quantity required for the experiments, the bottle was then sealed again, as well as another test phial of pulvis antimonialis.

The smaller figure in the back row farthest left says: " $D-n$ opiates-I hate themGlauber's salts \& ginger I say". This could be Thomas Beddoes (1760-1808), chemist and physician at Bristol, founder of the Pneumatic Institute at Clifton. He only participated in the influenza literature in June of 1803. A comparison with his portrait in profile, drawn in pencil from a painting by $\mathrm{E}$. Bird ${ }^{19}$ is not conclusive.

The other small figure confronting this last one is saying " $\mathrm{T}$ 'was the opiates did the good". It seems safe to assume that this is Dr. William Falconer (1744-1824). A portrait of him engraved by J. Fittler after Daniel ${ }^{20}$ shows him younger and slimmer, but the high forehead, the shape of the eyes and brows, and the concave line of the nose suggest one and the same identity in the satire and the portrait. The recommendation of opium in his saying can be traced as a general attitude in his practice

\footnotetext{
14 'Memoirs of the late Dr. Maxwell Garthshore', Gentleman's Mag., 1812, 387-391.

${ }^{15}$ A. H. Driver, Catalogue of engraved portraits in the Royal College of Physicians, London, Royal College of Physicians, 1952, p. 64.

16 Gentleman's Mag., op. cit., note 14 above, pp. 390-391.

17 Burgess, op. cit., note 7 above, no. 2258.

18 George Pearson, 'Some observations to investigate the composition of James's powder', Phil. Trans. R. Soc. Lond., abridged, vol. XVII(81), from 1791 to 1796, London, C. \& H. Baldwin, 1809, p. 91.

19 Rurgess, op. cit., no. 7 above, no. 227.1.

${ }^{20}$ Ibid., no. 941.
} 


\section{Short Articles}

from his work on influenza of $1803^{21}$ (the month in which he wrote this article can not be ascertained); here he writes; "Opiates I constantly found to be among the most necessary remedies."

There remains still one small figure to identify positioned to the far right of the group. It is the head partly cut off by the picture frame and reaching only half-way up the back of the tall Maxwell Garthshore. This seems to be a younger man. His saying is: "It was Broadbum's syrup of butterflies was superior to everything". It is here suggested that this figure might represent Sir George Smith Gibbes, M.D., F.R.C.P. (1771-1851). ${ }^{22} \mathrm{He}$ obtained his M.D. degree at the age of twenty-eight years and was admitted a Candidate of the Royal College of Physicians in June of 1803, became Fellow in 1804. Although he was not one of the Fellows at the date of this print, in April 1803, his comparative early achievements could have made him sufficiently conspicuous to figure as a deliberately small and only partially visible person hanging on to a group of high-ranking doctors. His portrait painted by John Keenan in 1798 at the Royal College of Physicians ${ }^{23}$ shows similar rounded features to the head in the satire. One of his early works is titled Observations on the component parts of animal matters, and on their conversion into substance resembling spermaceti (Bath, 1796). Conversion of animal matter into a substance for the manufacture of candles would in the language of a brilliant satirist correspond to syrup won from butterflies which Dr. Gibbes in his saying calls "superior to everything".

\footnotetext{
$21 \mathrm{~W}$. Falconer, An account of the epidemic catarrhal fever, commonly called the influenza, as it appeared at Bath, in the months of May and June 1782, Bath, [1782], p. 23.

${ }_{22}$ Munk, op. cit., note 6 above, vol. 3, p. 13.

${ }^{28}$ Royal College of Physicians, op. cit., note 11 above, p. 183.
} 